\title{
MEASURING THE INCIDENCE OF NANOPARTICLES IN THE WORKPLACE ATMOSPHERE WITH A FOCUS ON THE WOODWORKING AND ENGINEERING INDUSTRIES
}

\author{
${ }^{1}$ Petra ROUPCOVÁ, ${ }^{1,2}$ Karel KLOUDA, ${ }^{1}$ Ondřej CHROMEČKA, ${ }^{1}$ Simona SLIVKOVÁ, \\ ${ }^{3}$ Hana KUBÁTOVÁ \\ ${ }^{1}$ VSB- Technical University of Ostrava, Ostrava, Czech Republic, EU, petra.roupcova@vsb.cz; \\ simona.slivkova@vsb.cz \\ 2Occupational Safety Research Institute, Prague, Czech Republic, EU, klouda@vubp-praha.cz \\ ${ }^{3}$ State Office for Nuclear Safety, Prague, Czech Republic, EU, hana.kubatova@sujb.cz
}

https://doi.org/10.37904/nanocon.2021.4366

\begin{abstract}
Nanoparticles are present in everyday life including industry, and this article focuses mainly on their occurrence in the work environment. We measured the concentration of nanoparticles in anthropogenic activity, where nanoparticles are generated as unwanted waste. Two plants were selected for such measurements. In the first plant we measured nanoparticles based on metals, while in the second we measured nanoparticles of organic origin, specifically wood. This article also deals with the possible toxic effect of nanoparticles on the environment. The procedures of ISO / TR 27628 - workplace atmospheres - ultrafine, nanoparticle and nanostructured aerosols - inhalation exposure characterization and assessment were applied to identify the key sites in both plants that produced the largest number of nanoparticles. We suggest the provision of protective work funds in an environment with a risk of nanoparticles according to the certified methodology of the Ministry of Labour and Social Affairs.
\end{abstract}

Keywords: Nanoparticles, aerosols, wood, metal, toxicity, safety measures

\section{INTRODUCTION}

Nanoparticles are formed in natural processes (volcanoes, forest fires, etc.), in anthropogenic activities, and as "waste" in many industrial productions. However, they are being increasingly produced in artificial ways, for example in the production processing of nanofibers. [1,2]. This paper presents the measurements of nanoparticle concentrations in the size $10-700 \mathrm{~nm}$ produced at two plants that work respectively with steel and wood:

1) Metrostav a.c. Division 3 - steel (source of nanoparticles from steel),

2) Iktus Furniture-wood (source of nanoparticles from wood).

In assessing the measurement results, we followed the ISO/TR 27628 standard - workplace atmospheres ultrafine, nanoparticle and nano-structured aerosols - inhalation exposure characterization and assessment, with the aims of:

- $\quad$ determining the expected composition of the aerosol particulate matter and estimating/determining its toxic effect (wood vs steel). [3,4]

- $\quad$ registering the airflow with aerosol transport in the workplace (doors, windows, controlled ventilation),

- $\quad$ analysing work activities, technologies used, work habits/behaviour of employees.

Chemical composition of wood may have plenty of variations. Apart from its main components (cellulose, hemicellulose and lignin) it consists of e.g. phenols, tannins, alkaloids which may cause adverse biological 
activity. Exotic woods (pointed shape) resemble asbestos in their behavior towards the organism [5]. In metallurgical operations it is important to count with heavy metals which inhibit cell division (oxidative stress) [6].

Subsequently, we addressed the employer/operator with questions/suggestions on:

- modifications to the working atmosphere (natural ventilation, central, local, mobile exhaust, air curtains, air filtration through hepa filters, and ideally the extraction of emissions and ventilation,

- measures of a technological or technical nature (change of technology and production method, installation of CNC machines, mobile walls, air curtains, placing production or part of it in a hermetic box or fume cupboard, change of raw material,

- modifications of an organisational nature (continuous prevention policy, control zones, precautionary principle, cleanliness of the workplace - regular cleaning, maintenance, reduction of staff at the main source of nanoparticles),

- $\quad$ introduction of respiratory protective equipment (possibility of using the certified methodology of the Ministry of Labour and Social Affairs, having a good and sufficient quantity of PPE and OPDO [7]; respiratory protection with PPE should be applied as the last option of the measures to protect against nanoparticles in the working environment;

- $\quad$ introduction of specialised occupational medical examinations (e.g. biological monitoring - SZU, Department of Occupational Medicine, $1^{\text {st }}$ Faculty of Medicine, Prof. Daniela Pelclová - Measurement of unsaturated aldehydes in breath.

\section{MEASUREMENT OF THE HALL SPACE DURING THE PRODUCTION OF A DOOR COMPONENT}

The measurement of nanoparticle concentrations was carried out in a unique production process, namely the production of chamber gates.

The Gabčíkovo waterworks chamber gate production site consists of three interconnected halls (Figure 1) and a paint shop. The basis of the production technology is the application of welding techniques* for welding steel plates into complex technological units whose size and shape are influenced by their transport to the site and their assembly in the chamber of the waterworks.

*Technologies used in hall welding:

- manual arc welding with fusion electrode

- $\quad$ arc welding with filled electrode in active gas

- $\quad$ submerged arc welding with multiple wire electrodes

- $\quad$ arc fusion welding in active gas

- $\quad$ submerged arc welding with wire electrode

- flame welding

- $\quad$ tungsten arc welding in inert gas

- oxygen cutting stroke welding of bolts

- plasma cutting

- $\quad$ electric arc grooving with compressed air
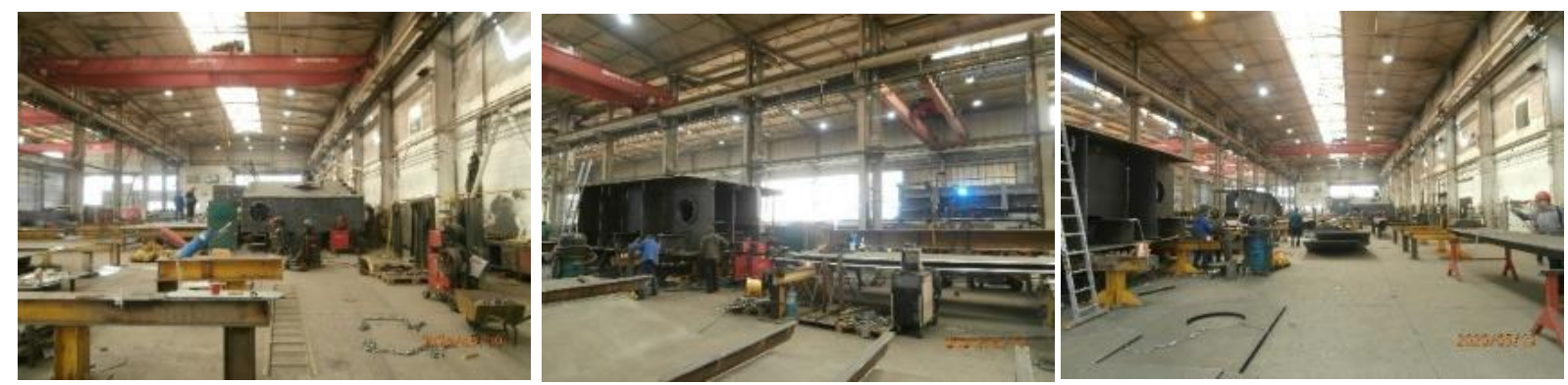

Figure 1 Illustrative photographs of the three halls of the machine area 
The first type of measurement, which aimed to map the working environment in the halls, was divided into two days at 09:00 - 10:00 o'clock when the majority of welders and turners (about 20 employees) were carrying out their specific work activities.

The measuring instrument The Testo Disc mini 133 device was used for measuring a whole passage between the technologies in three halls and a height of $1 \mathrm{~m}$ from the floor. The obtained nanoparticle concentration results and mean particle diameters have been processed in graphs (Figures 2, 3, 4, 5).

The measured values were influenced by the location in the hall in relation to the technological operation that took place near the measuring instrument. In general, it can be concluded that the air in the halls as a whole fails to be optimal. Ventilation of the halls is provided through air vents - on the columns and naturally through windows located around the perimeter of the hall or through open doors.

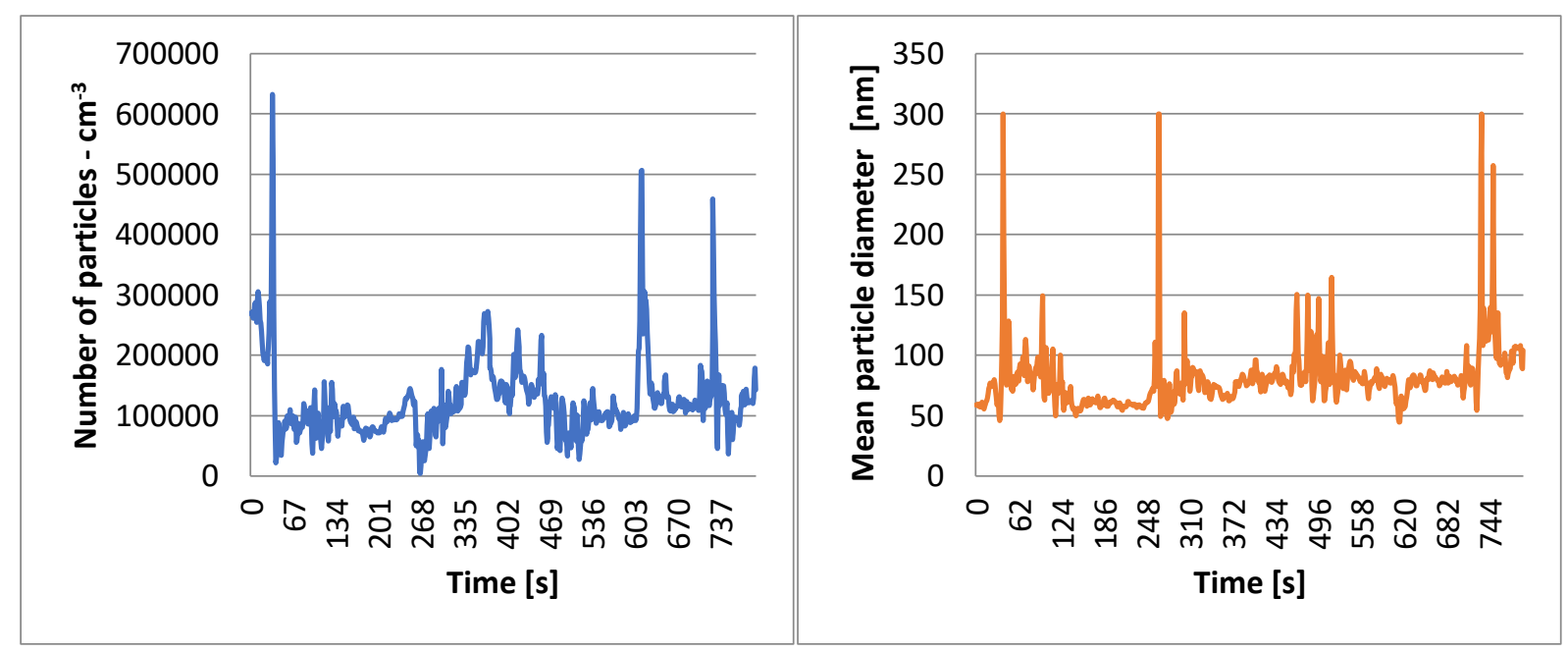

Figure 2 Concentration and mean diameter of nanoparticles as they pass through the halls

\section{MEASUREMENTS IN SELECTED TECHNOLOGICAL (WELDING) OPERATIONS}

After measurements at unspecified locations in the halls, we measured nanoparticle concentrations at selected welding operations, namely at the hole of the closed segment (max. 400,000 \#-cm ${ }^{-3}$ ), at the open segment

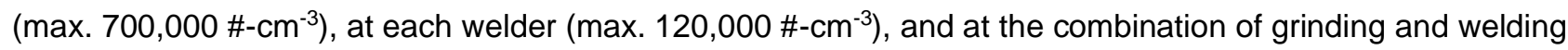
(max. 160,000 \#-cm-3).

\section{HALL VENTILATION}

Hall ventilation is provided through the central air conditioning vents and naturally through windows located around the perimeter of the hall and through open doors. Ventilation in the halls is provided by supplying "filtered" air to the vents located next to the supporting columns.

The aim of this measurement was to investigate the effect of the air handling system and to compare the concentration of nanoparticles at the exhaust (measuring instrument located about $20 \mathrm{~cm}$ from the mesh) and the hall area (about $2 \mathrm{~m}$ from the mesh). The measurements were performed by moving the instrument in the space to a distance of $2 \mathrm{~m}$ from the exhaust after about $1 \mathrm{~min}$. Measurements were taken at two separate vents located in the centre of the hall.

We assumed the same values of nanoparticle concentration at $20 \mathrm{~cm}$ from the mesh for both vents and higher values after displacement (after $1 \mathrm{~min}$ ) compared to the values measured at the mesh. Our assumption was not confirmed since the same concentration pattern of nanoparticles was measured over time and distance (20 $\mathrm{cm}$ versus $2 \mathrm{~m})$. The measured nanoparticle concentration was higher for the first vent $(80,000-100,000$ 
\#-cm ${ }^{-3}$ ) compared to $60,000 \#-\mathrm{cm}^{-3}$ for the second measurement, but here the mean particle concentration was lower (Figure 3).

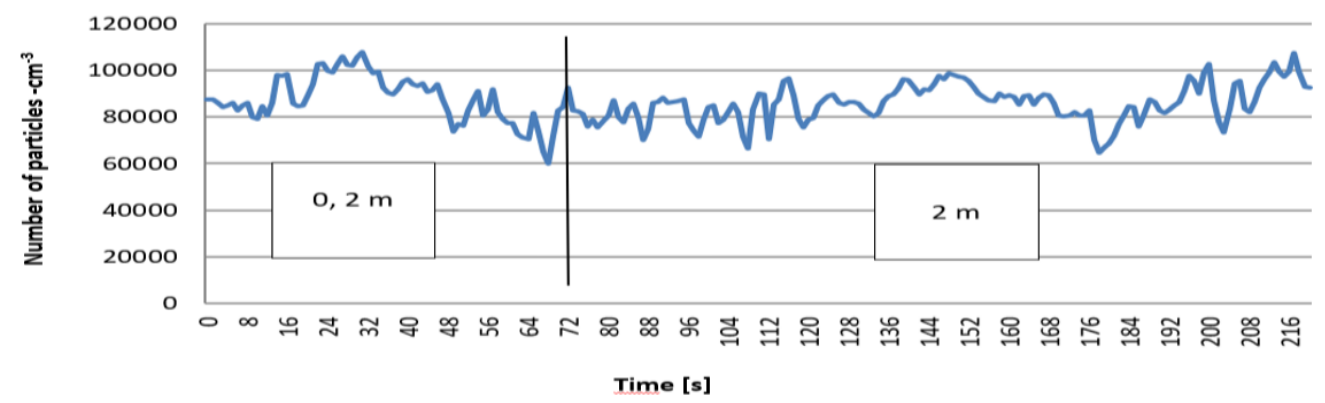

Figure 3 Concentration of nanoparticles at different distances from the exhaust ( ${ }^{1 s t}$ exhaust)

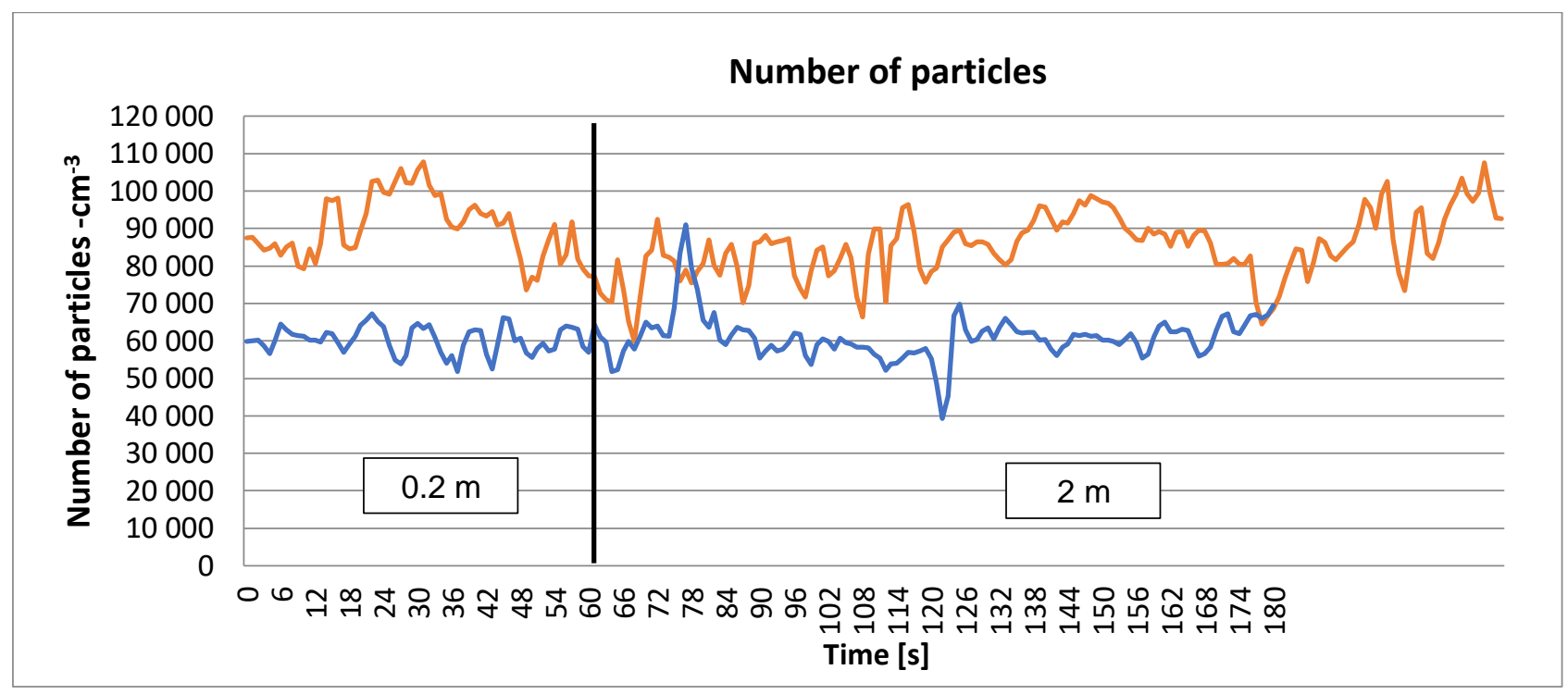

Figure 4 Comparison of the particle number concentration of two forced ventilation flows

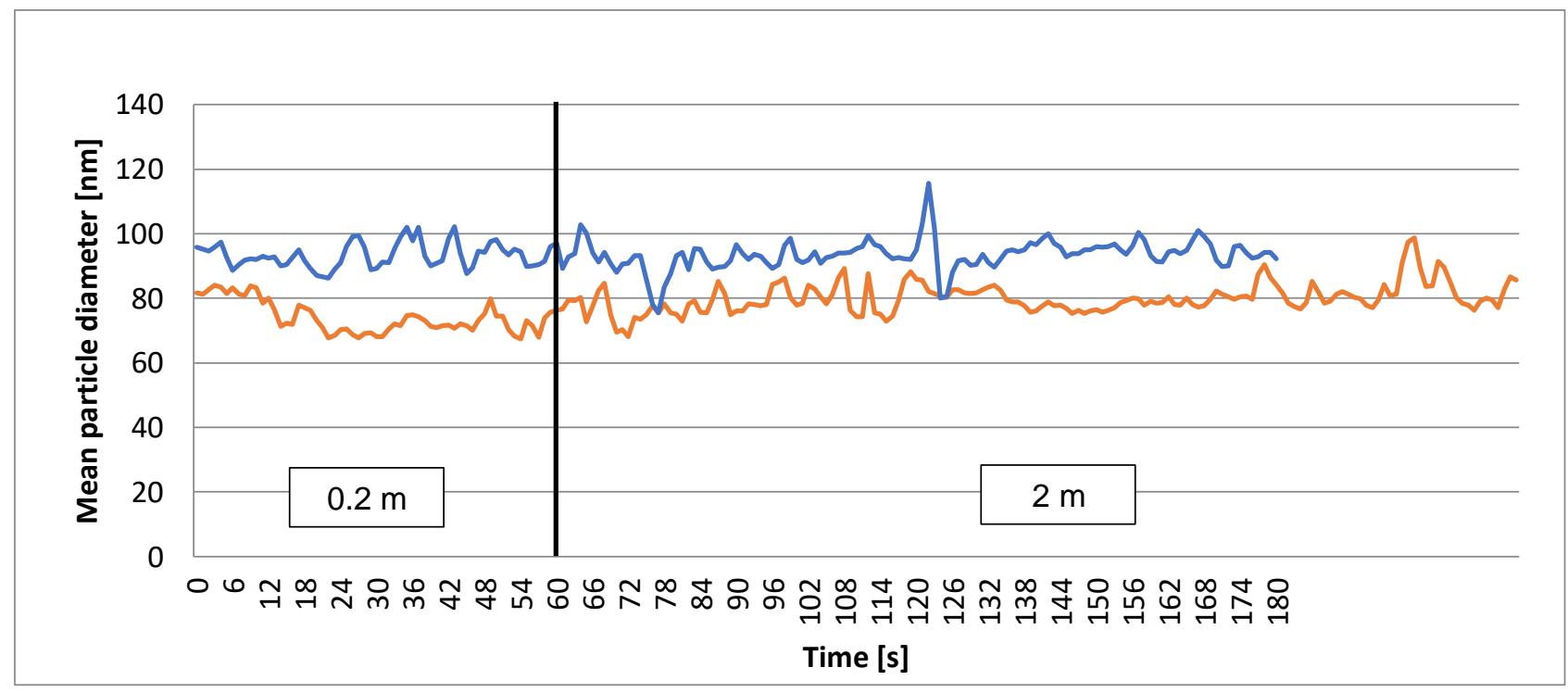

Figure 5 Comparison of mean particle diameters of two forced ventilation flows 


\section{MEASUREMENT OF NANOPARTICLE CONCENTRATION IN FURNITURE PRODUCTION}

Furniture production covers many areas, yet the production of classic corner benches, dining sets, wardrobes, beds, chests of drawers predominates. Most technological operations are carried out with the use of CNC machines. For example, cutting saws, taping machines and doweling machines are used for drilling, milling, and cutting. Most of the CNC machines are located in the production Halls 1 and 3.

The measurements were performed while walking with the measuring device through the halls $(1-4)$, with the measuring device placed at a height of about $1 \mathrm{~m}$ above the floor surface. The obtained partial results are presented in the form of graphs (Figures 6 and 7) as the change in the number of particles per unit volume of the atmosphere over time and the change in the size of the diameter over time in each production hall.

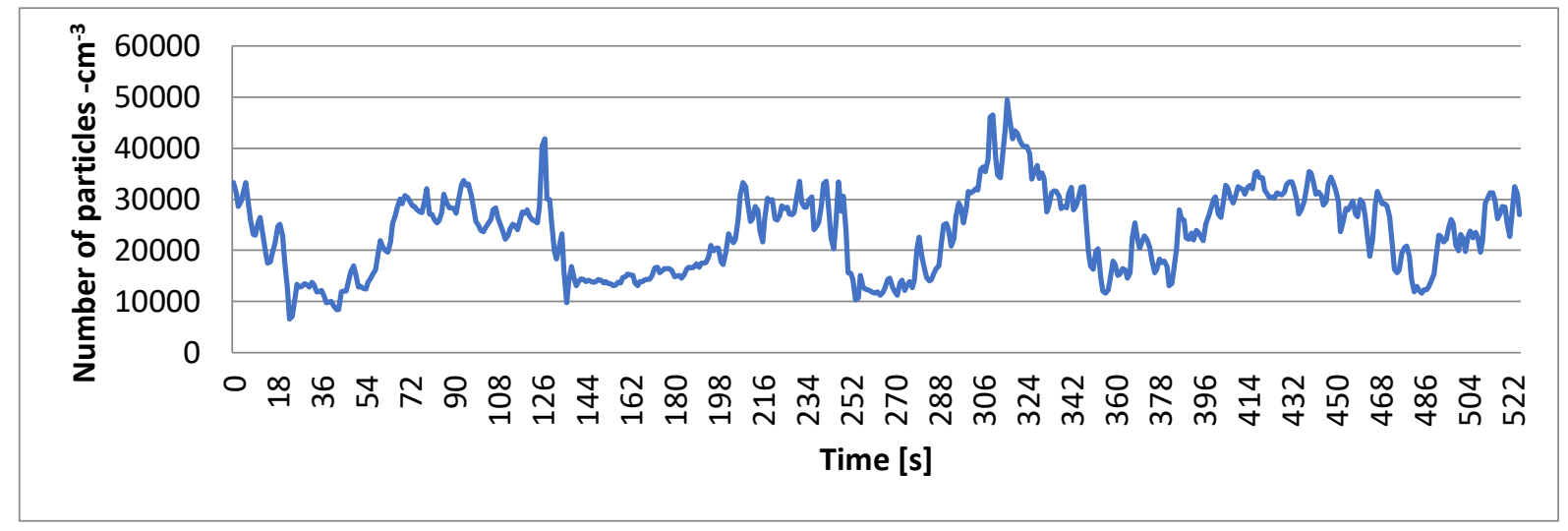

Figure 6 Nanoparticle concentration in Hall 3

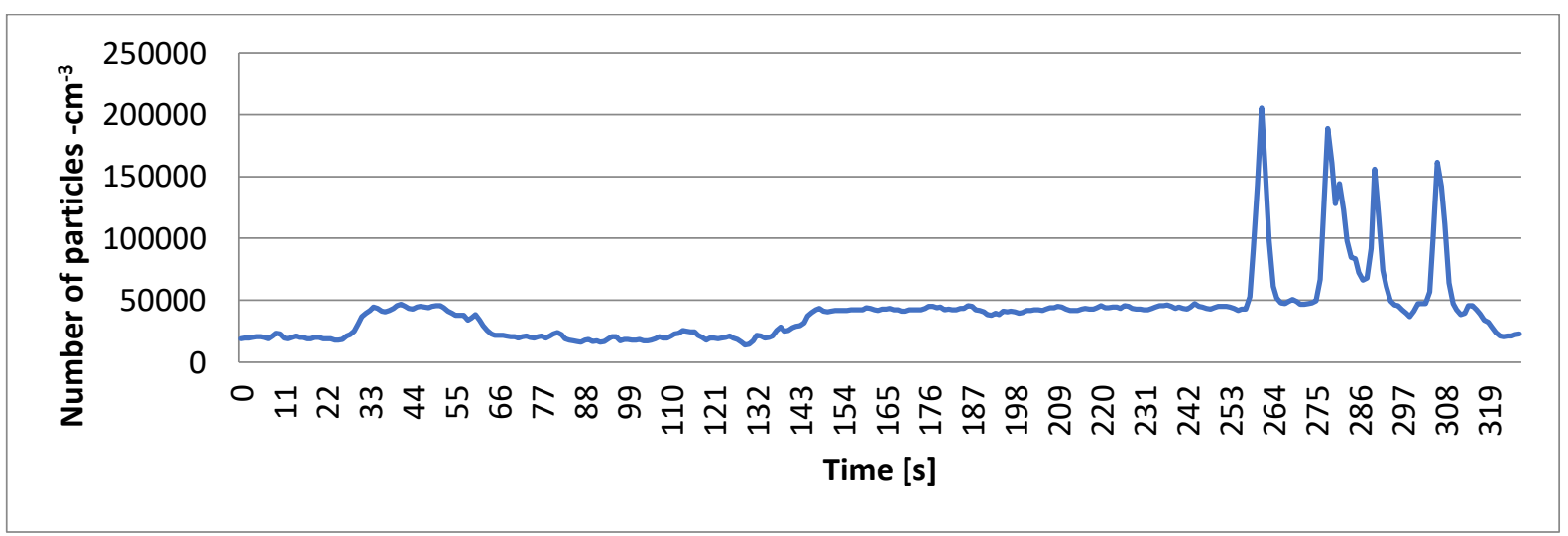

Figure 7 Nanoparticle concentration in Hall 4

\section{HALL 1}

The jump increase in nanoparticle concentration was measured at the CNC forming saw, where the values obtained reached a magnitude of about $150,000-200,000 ~ \#-\mathrm{cm}^{-3}$ as the semi- finished product exited the machine.

\section{HALL 2}

In this hall, we identified from the measurement values the area where the nanoparticles are localized, namely at the lower cutter near the free suction necks. Here their concentration ranged from 200,000 to 300,000 \#$\mathrm{cm}^{-3}$. 


\section{HALL 3}

In this hall, where the CNC machines are located, there is a fairly regular pulsation of nanoparticle concentration values (Figure 6) from $10,000 \#-\mathrm{cm}^{-3}$ to $35,000-50,000 \#-\mathrm{cm}^{-3}$ with stable values of mean particle diameter - 40-50 nm.

\section{HALL 4}

Hall 4 houses press doweling machines and a circular saw, which is fitted with a plastic guard with an exhaust connection. However, concentrations with pulsating values of up to $200,000 \#-\mathrm{cm}^{-3}$ were measured in the vicinity of the operating worker (Figure 7) and with a decrease in the mean particle diameter from $28 \mathrm{~nm}$ to 17 nm.

\section{CONCLUSION}

The measurements in Hall 1 at the exit of the semi-finished product from the machine show that even an efficient CNC machine does not prevent the accumulation of nanoparticle concentrations. By failing to design the hall exhaust accurately, a significant increase in the concentration of nanoparticles in the work area can occur. In particular, the circular saw, even when connected to an exhaust, is a source of high nanoparticle concentrations. A surprising finding at MetroState Division's was the discovery that the air in the halls circulates without filtration. If we want to compare the possible toxic effect of wood against steel, we must consider not only the main role of concentration but also the composition, shape of nanoparticles and the ambient conditions with which they enter the working area [4].

\section{ACKNOWLEDGEMENTS}

The publication was written within the Student grant competition "Release of Nano and Microplastics from Nanotextiles and Determination of Their Effect on the Environment" - project number SP2021/69.

\section{REFERENCES}

[1] ALBA, J., ROUPCOVA, P., KLOUDA, K. Nanotechnology Safety and Security: Nanoparticles and Their Impact on the World. In Safety and Security Issues in Technical Infrastructures. Edited by REHAK, D., BERNATIK, A., DVORAK, Z., HROMADA, M. HERSHEY, PA: IGI Global, 2020, pp. 321-352. Available from: https://doi.org/10.4018/978-1-7998-3059-7.ch012.

[2] ROUPCOVA, P., KLOUDA, K., NECHVATAL, M., BATRLOVA, K., BERNATIKOVA, S. New risks in OHS with focus on selected nanotechnological workplaces. Proceedings of the 29th European Safety and Reliability Conference, ESREL 2019. Hannover: ESREL, 2020, pp. 3911-3916.

[3] KLOUDA, K., SINAY, J., CEJPEK, J., LACH, K. Identification of Nano- and Microparticle Aerosols Generated in Selected Operations. Acta Mechanica Slov. 2013, vol. 17, no. 2, pp. 90-102. Available from: https://doi.org/10.21496/ams.2013.025.

[4] NEL, A., XIA, T., MADLER, L., LI, N. Toxic potential of materials at the nanolevel. Science. 2006, vol. 311, pp. 622-627.

[5] JANKOVSKY, M., LACHMAN, J., STASZKOVA, L. Wood chemistry. Prague: Czech University of Agriculture, 1999. ISBN 80-213-0559-2.

[6] KAFKA, Z., PUNCOCHAROVA, J. Heavy metals in nature and their toxicity. Chemicke listy. 2002, vol. 96, pp. 611- 617.

[7] Certified methodology for the provision of personal protective equipment in an environment with a risk of nanoparticles (aimed at employers in addressing the need to assign personal protective equipment for respiratory protection). Prague: Research Institute of Occupational Safety, v. V. I, 2016. 